\title{
Activity in the labor market and the economic crisis: Gender differences in Galicia
}

\author{
María Carmen Sánchez-Sellero ${ }^{1}$, Xosé Manuel Martínez-Filgueira ${ }^{1}$, Pedro Sánchez-Sellero ${ }^{2}$ \\ ${ }^{1}$ Universidade da Coruña, ${ }^{2}$ Universidad de Zaragoza (Spain) \\ c.sanchez@udc.es,xose.martinez@udc.es,pedross@unizar.es
}

Received September, 2014

Accepted January, 2015

\section{Abstract}

Purpose: This paper studies personal characteristics that determine labor activity in Galicia.

Design/methodology/approach: The data are from the Galician Statistics Institute (IGE) Family Living Conditions Survey (ECV). We estimate the model parameters via binary logistic regression; then we calculate the probability of activity according to various personal characteristics. We find that probability varies according to the gender. We analyze three periods: economic growth (2003), the year the economic crisis began (2007), and the economic crisis (2012).

Findings: In general, the probability of activity during the economic crisis is higher than during economic growth. We find that people enter the labor market younger during economic growth and retire later during the economic crisis. Women participate in the labor market at lower raters after the birth of their children in 2003 and in 2007; this rate rises in 2012. This is due to the high cost of childcare for families with scarce economic resources.

Research limitations/implications: Future researches could study the crisis context which reduce the gender differences in labor market.

Practical implications: The gender differences are reducing and the economic cycle plays a relevant role. 
Originality/value: We show through repeating the analysis in different periods that the cycle involves different behaviors in the probability of activity by gender. Overall, during the crisis, the probability of activity are bigger and the gender differences are smaller.

Keywords: Labor market, Activity, Gender, Logit, Crisis

Jel Codes: C13, C25, J01, J16

\section{Introduction}

The labor market in Spain is a hot topic. The Spanish economic crisis, which began in 2008, strongly affects the labor market and has created a $24.47 \%$ unemployment rate in the second quarter of 2014. Continuous labor market reforms intended to reduce unemployment cause concern and sensitivity, however, about when the Spanish economy will begin to create jobs again.

Using data from the Spanish region of Galicia, we evaluate the personal characteristics of people who try to access the labor market. Specifically, we believe that gender has a major influence on labor markets. Accordingly, our study covers three years: 2003 (a period of economic growth), 2007 (the beginning of the economic crisis), and 2012 (when the Spanish economy continues to suffer from the crisis). We believe our results and conclusions for this region are equally valid for Spain as a whole.

We study the activity model in the mentioned years, and we compare gender influence in different economic periods. Specifically, we want to know if economic cycles affect the probability that women or men will be active in the labor force. Thus, our study has two objectives: to determine how gender affects the probability of activity in the labor markets, and to determine how gender affects the impact of the economic cycle. Using binary logistic regression, we achieve these objectives by repeating the analysis for years of economic growth and economic crisis.

This paper is structured as follows. Section 2 reviews the literature analyzing the gender influence on the labor market. Section 3 summarizes briefly the Galician labor market in previous years and during the current economic crisis. Section 4 describes the data and defines the variables in the activity model. Section 5 explains the model and uses binary logistic regression. We also present the main results about the probabilities of activity, and we offer some graphical representations that support these results. Section 6 concludes. 


\section{Review of the literature on gender in the labor market}

The influence of gender on the labor market is a widely discussed topic in many disciplines. Lamas (2000), for example, finds that gender is a cultural construction of sexual differentiation. According to Sánchez and Delicado (2007), sex reflects differences in biology, whereas the concept of gender reflects differences in cultural and social characteristics associated with biological characteristics. The labor market reflects the economic and social consequences of gender inequalities.

Empirical evidence in Moltó, Peraita de Grado, Sánchez and Uriel (1994) suggests that there are two primary kinds of job search systems: the Spanish Employment Institute (INEM) and personal relationships. Women use formal job-search methods more often than men (Valencian Institute of Economic Research, IVIE, 2006).

The human-capital theory (Becker 1962, 1971, 1985) states that women also experience occupational segregation. According to Gradín, Otero and Arévalo (2003), occupational segregation occurs when women's labor participation falls into a narrow range of occupations due to external factors. These factors originate in the education system, in family socialization, or in the labor market if employers prefer men or women for certain activities. From this perspective, the labor market in Galicia is a viable study area because it exhibits large differences in the positions, presence, and remuneration of men and women (Del Río, 2003).

The theory of dual labor markets therefore applies to Galicia. According to Larrañaga (2000), the basic hypothesis is that a labor market has two segments: the primary or central sector, and the secondary or peripheral sector. The primary sector offers jobs with high wages, opportunities for improvement, good working conditions, and job security; the secondary sector offers lower-paid positions, worse conditions, instability, and turnover among workers. Some groups, such as women, can be integrated in a secondary market. Goldin (1986) and Bulow and Summers (1986), among others, analyze this theory.

In today's labor markets, younger generations tend to have a higher level of training. Some years ago, there were more male than female college graduates; these differences have disappeared, however. Today, more women than men have degrees in many areas. The average worker spends 9.86 years in school, yet women spend 10.52 years and men spend 9.49 years. In other words, busy women have a $10 \%$ more years of education than men (IVIE, 2008a). However, access to the labor market is different for women and men. These differences are most evident among less educated women. Along these lines, Oguiza, Gallastegui and Núñez (2004) propose a descriptive analysis of employed women by level of training. 
It is clear that access to higher education increases labor market participation. In addition, the behavior among men and women is similar in the labor market if the educational level is higher in both genders. Currently, however, younger women have more education than younger men but this situation has not been accompanied by similar changes in the labor market.

According to IVIE (2008b), labor participation rates and wages are much more similar for men and women in younger generations than in older generations. Today, there are two significant changes in the process of integrating women into the labor market: social acceptance of female employment and active participation of women in the labor market. We assume that the decision to participate in the labor market depends on marital status, age, and education level.

Studies of the transition from school to the labor market show that women access and leave the labor market at the same rate as men, but women are less successful than men. This is because a lower proportion of women get jobs and a higher proportion of women lose their jobs. After leaving school, men are more likely to be employed than women (Albert, Juárez, Sánchez \& Toharia, 2003).

The increase in the labor force in recent years is mainly due to the entrance of women. In Spain, this explains why differences in activity rates between men and women are significantly lower. In contrast, the reduction is less noticeable in employment, because unemployment affects more active women, regardless of their training. Unemployment rates are still higher for women of all education levels (Frutos \& Titos, 2001).

Factors that affect women in this regard can be both external and internal. A primary external factor is family commitments. Women have a double workday (they work inside and outside the home), which creates disadvantages for their full integration into the labor market. The difficulties of juggling work at home with paid jobs can hinder their career progress and decrease their value to employers. This discontinuous job cycle thus hinders opportunities for professional development among women, though this tends to be less of a disadvantage in younger generations. Accompanying this is low birth rates. Internal factors are related with the cultural field.

Additionally, few women were company managers until recent years. In contrast, today's highly qualified female population has changed that. In this sense, Guzmán and Rodriguez (2008) find that women adopt different behavior patterns from men in business. Rosener (1990) also finds different behavior in female business managers. 
Riobóo and Martin (2011) study the level of equality or inequality in the labor market in Galicia and Spain by obtaining a synthetic index (Gender Inequality in Labour Market, GILM) to quantify the differences between genders. The index separates variables by gender.

We also disaggregate variables by gender, but for other purposes. The dependent variable is dichotomous and gender is a part of the definition of all explanatory variables. The difference of this paper in relation to previous literature is that we calculate the probability that a person is active or inactive under certain assumptions and different points in time, corresponding to periods of economic stability as well as economic crisis.

\section{Basic features of the labor market in Galicia in previous years and during the economic crisis of 2008}

Méndez (2000) states that one of the characteristics of the Galician labor market is the lack of participation of the working-age population in productive activities. In recent decades in Galicia, weak growth of the working-age population has not led to job growth, as happened in Spain. In Galicia, activity levels declined due to increases in retirements and the loss of agricultural and fishing employment. The younger population has not replaced these workers.

The fall in labor demand was greater than the fall in job growth and the unemployment rate is close to the national average. The major problems reside in the younger female demographic, which has double the unemployment rate of men in all sectors of the population other than people over 55.

Ares and Rey (2008) state that Galicia has a stabilized and aging population, which is greater than in other economies. This does not favor a dynamic labor market or the creation of jobs and wealth, however. The Galician labor-market activity rate decreased (in the previous years of the 2008 economic crisis), for instance, due to low female participation in the labor market and is worse than in the Spanish economy. The Galician occupation rate is not better; it increased less than in Spain due to fewer workers in the primary sector and difficulties other productive sectors had in absorbing those jobs. However, it is surprising that Galician industrial employment in relative terms is now higher than in Spain.

We must emphasize the enormous training progress of Galician workers, because the number of workers with college degrees grew much more than the Spanish average, especially in women. In recent years, Galicia experienced a remarkable increase in the working population. 
Data from the Galician Operational Program of the European Social Fund in the period 20072013 (Xunta de Galicia, 2007) show that the activity rate for 1996-2007 has a remarkable procyclical behavior but increases at a slower rate than the national. The continued aging of the Galician population partially offsets this rise.

Table 1 reflects the realities of the Galician labor market in terms of subsequent empirical models (analysis of activity by gender in Galicia). In terms of the Xunta de Galicia (Work Regional Ministry) Ibermovilitas study (2010), the active population is the number of people older than 16 years of age who are working (occupied population), as well as the number of people who are looking actively for work (unemployed population). The Galician labor market before the crisis shows increasing employment and labor participation for both men and women, though at different rates (2000-2007). These amounts radically change in the economic crisis period (2008-2012) (see table 1).

Since 2008, labor participation decreases for men but increases for women, employment decreases less for women, and the increase in unemployment is lower. Thus the current tendency is better for women than for men.

\begin{tabular}{|c|c|c|c|c|c|c|}
\cline { 2 - 6 } \multicolumn{1}{c|}{} & \multicolumn{3}{c|}{ Men } & \multicolumn{3}{c|}{ Women } \\
\hline $\mathbf{2 0 0 0}$ & Activity & Occupation & Unemployment & Activity & Occupation & Unemployment \\
\hline $\mathbf{2 0 0 1}$ & 61.8 & 55.4 & 10.3 & 41.7 & 32.9 & 21.0 \\
\hline $\mathbf{2 0 0 2}$ & 61.0 & 56.7 & 7.8 & 40.0 & 33.8 & 15.5 \\
\hline $\mathbf{2 0 0 3}$ & 62.2 & 57.0 & 8.2 & 40.8 & 33.7 & 17.5 \\
\hline $\mathbf{2 0 0 4}$ & 62.6 & 56.9 & 8.4 & 43.0 & 35.1 & 18.4 \\
\hline $\mathbf{2 0 0 5}$ & 62.6 & 58.1 & 7.2 & 44.6 & 36.0 & 19.3 \\
\hline $\mathbf{2 0 0 6}$ & 62.2 & 58.4 & 6.1 & 44.3 & 38.3 & 13.5 \\
\hline $\mathbf{2 0 0 7}$ & 63.3 & 59.7 & 5.7 & 46.0 & 40.5 & 11.4 \\
\hline $\mathbf{2 0 0 0 - 2 0 0 7}$ & $\mathbf{1 . 5}$ & $\mathbf{4 . 3}$ & $\mathbf{- 4 . 6}$ & $\mathbf{4 . 3}$ & $\mathbf{8 . 5}$ & $\mathbf{- 1 1 . 0}$ \\
\hline $\mathbf{2 0 0 8}$ & 63.7 & 59.0 & 7.4 & 47.2 & 42.3 & 10.4 \\
\hline $\mathbf{2 0 0 9}$ & 62.5 & 55.1 & 11.8 & 48.5 & 41.9 & 13.6 \\
\hline $\mathbf{2 0 1 0}$ & 61.8 & 52.8 & 14.6 & 48.0 & 40.1 & 16.3 \\
\hline $\mathbf{2 0 1 1}$ & 61.7 & 51.4 & 16.6 & 49.2 & 40.2 & 18.3 \\
\hline $\mathbf{2 0 1 2}$ & 61.6 & 48.8 & 20.9 & 49.7 & 39.5 & 20.4 \\
\hline $\mathbf{2 0 0 8 - 2 0 1 2}$ & $\mathbf{- 1 . 7}$ & $\mathbf{- 1 0 . 9}$ & $\mathbf{1 5 . 2}$ & $\mathbf{3 . 7}$ & $\mathbf{- 1 . 9}$ & $\mathbf{1 0 . 4}$ \\
\hline
\end{tabular}

Table 1. Activity rate, occupation, and unemployment in Galicia by gender (2000-2012), in percentages. EAPS 2013, Methodology 2005 (IGE- INE)

\section{Empirical analysis: Definition of variables}

Our empirical analysis is based on the study of the probability of labor-market activity. We introduce both qualitative and quantitative variables. The most remarkable qualitative variable is gender, but we also introduce formation level, age and municipality, among others. We 
generate categorical and quantitative variables through their interaction with gender. The interaction of gender with the other explanatory variables is essential to understand how different factors influence decisions.

We call our model the activity model. We apply binary logistic regression (Agresti, 1996; Amemiya, 1981; Cox \& Snell, 1989; Hosmer \& Lemeshow, 1989) to represent in a graphical way the different probabilities under certain conditions.

As a first step of the activity model, we want to know the reasons, translated in terms of variables, that a person enters the labor market.

\subsection{Data}

We use microdata from the "Family's Living Conditions Survey" from the Galician Statistics Institute (Spain) for 2003, 2007 and 2012. The survey methodology was made in 2005. The "Family's Living Conditions Survey" is a statistical activity carried out annually. The sample size is 18572 people in 2003, representing a population of 2701425 residents of Galicia in this year. The total sample is 17619 people (for 2712520 of the population) in 2007 and 24057 people representing 2706158 in 2012 . This paper uses a smaller sample size due to its restriction to members of the population aged 20-64 (see Table 2). These data do not exactly match with the Municipal Register of Inhabitants.

\begin{tabular}{|l|r|r|r|}
\hline \multirow{2}{*}{\multicolumn{1}{|c|}{ SAMPLE SIZES }} & \multicolumn{3}{c|}{ YEARS } \\
\cline { 2 - 4 } & $\mathbf{2 0 0 3}$ & $\mathbf{2 0 0 7}$ & $\mathbf{2 0 1 2}$ \\
\hline Total & 10846 & 10387 & 13919 \\
\hline Men & 5342 & 5029 & 6812 \\
\hline Women & 5504 & 5358 & 7107 \\
\hline
\end{tabular}

Table 2. Sample sizes in Galicia of the population aged 20-64 by gender. IGE (2003, 2007, 2012), "Family's Living

Conditions Survey"

The ECV is a non-self-weighted sample for any data estimation; for this reason, we must apply the elevation factor for each register. The variable frep allows the extrapolation of survey data for total population. Thus, the total estimation of the $X$ characteristic is the sum of all registrations that present the same $(\mathrm{Xi})$ multiplied by their respective weighting factors $\hat{X}=\sum X i *$ frep $i$. 
Each person carries a weighting factor, so that all people have the same weighting factor. The sum of all weighting factors is the total of the Galician population.

We obtain activity rates by gender for the years 2003, 2007 and 2012 from the ECV (table 3). We show that the activity rates increase strongly, especially in the economic crisis year, 2012 and in women. These activity rates from ECV are higher than the activity rates from Economically Active Population Survey (EAPS) (table 1) because the ECV obtain these rates for the group 20-64 years old (the age range of the study), while the EAPS corresponds to people at least 16 years old.

\begin{tabular}{|l|c|c|c|}
\hline \multicolumn{1}{|c|}{ ACTIVITY RATES } & \multicolumn{3}{|c|}{ YEARS } \\
\cline { 2 - 4 } & $\mathbf{2 0 0 3}$ & $\mathbf{2 0 0 7}$ & $\mathbf{2 0 1 2}$ \\
\hline Total & 67.8 & 69.4 & 75.9 \\
\hline Men & 79.2 & 78.8 & 81.5 \\
\hline Women & 56.6 & 60.6 & 70.5 \\
\hline
\end{tabular}

Table 3. Activity rates by gender (2003, 2007 and 2012),

in percentages. IGE (2003, 2007 and 2012), "Family's

Living Conditions Survey"

Our method is the binary logistic regression, calculated using the statistical software R (R Core Team, 2012). The graphics are obtained with the Lattice software (Sarkar 2008) included in program $\mathrm{R}$.

\subsection{Variables}

We reflect the variables extracted from ECV and others created from them. We try to find out which make a person want to work and therefore, if the person is active or inactive. The dichotomous dependent variable equals 0 for inactive and 1 for active. We classify active people as occupied or unemployed. We make this classification with the variable relact (relation with the activity) obtained by ECV.

The bases of the definitions of the independent variables reside in the notion that men do not behave the same as women and therefore, gender has a special role in labor market models. Gender influences not only if a person is active or inactive, but also marital status, formation level, age, etc. (Sánchez, Fuentes \& Artacho, 2007).

Sánchez-Sellero (2010) proposes different labor-market models using variables such as gender, number of members, age, formation level and marital status on the basis of 
sociodemographic changes in the Spanish population. Our model uses these variables, specifically six categorical variables and two quantitative variables. We consider the categorical variables and the quantitative variables differently.

The categorical variables are gender, age groups, marital status, formation level, nationality and size of the municipality. The initial models include the following categorical variables, taking into consideration the importance of the interaction between gender and the other explanatory variables:

- Gender

- $\quad$ Age groups * gender

- Marital status * gender

- $\quad$ Formation level * gender

- Nationality $*$ gender

- $\quad$ Size of the municipality $*$ gender

Table 4 shows the different categorical variables and their corresponding categories, as well as quantitative variables.

We classify the variable formation level using the groups in the National Classification of Education (CNED), which is applied by the IGE.

The quantitative variables, as well as the categorical variables, also consider the relationship between their effect and the gender of the analyzed person. This interaction reflects the construction of categorical variables duplicating codes in the same variable (depending on gender), whereas we create one variable for each gender for the quantitative variables. Thus, the quantitative variables are the following: Family size $*$ gender and Corrected household earnings $*$ gender.

Family Size is the number of people who live in a household. This variable has a minimum value of 1 and a maximum value of 8 . We use the income variable of the ECV to construct corrected household earnings. We measure the incomes in thousands of Euros per month and construct this variable in two steps.

First, similar to Sánchez-Sellero (2010), total income is the sum of income from paid employment, self-employment, unemployment subsidies, rents and other incomes. According to Sánchez-Sellero (2010), all household income sources are relevant in an individual's decision to participate in the labor market, except those generated by the labor market. 
Accordingly, corrected household earnings is the total household income minus labor income, whether paid employment or self-employed and unemployment subsidies. Therefore, this variable measures the household income that does not depend on the labor market. The higher corrected household earnings, the less a person has to work, because other income covers his or her basic necessities. In turn, corrected household earnings are not equal for all household members.

\begin{tabular}{|c|c|c|}
\hline $\begin{array}{l}\text { TYPE OF } \\
\text { VARIABLE }\end{array}$ & ATTRIBUTES & MODALITIES \\
\hline \multirow{24}{*}{$\begin{array}{l}\text { Categorical } \\
\text { variables }\end{array}$} & \multirow{2}{*}{ Gender } & Men \\
\hline & & Women \\
\hline & \multirow{4}{*}{ Marital status } & Single \\
\hline & & Married \\
\hline & & Separated or divorced \\
\hline & & Widower or widow \\
\hline & \multirow{9}{*}{$\begin{array}{c}\text { Age groups } \\
\text { (5-year periods) }\end{array}$} & From 20 to 24 years \\
\hline & & From 25 to 29 years \\
\hline & & From 30 to 34 years \\
\hline & & From 35 to 39 years \\
\hline & & From 40 to 44 years \\
\hline & & From 45 to 49 years \\
\hline & & From 50 to 54 years \\
\hline & & From 55 to 59 years \\
\hline & & From 60 to 64 years \\
\hline & \multirow{5}{*}{ Formation level } & Illiterate and primary studies \\
\hline & & First period of secondary studies \\
\hline & & Second period of secondary studies \\
\hline & & Advanced vocational training \\
\hline & & University studies \\
\hline & \multirow{2}{*}{ Nationality } & Spanish \\
\hline & & Foreign \\
\hline & \multirow{2}{*}{$\begin{array}{l}\text { Size of the } \\
\text { municipality }\end{array}$} & Small: fewer than 20,000 habitants \\
\hline & & Big: more than 20,000 habitants \\
\hline $\begin{array}{l}\text { TYPE OF } \\
\text { VARIABLE }\end{array}$ & VARIABLES & \\
\hline \multirow{2}{*}{$\begin{array}{l}\text { Quantitative } \\
\text { variables }\end{array}$} & Size of the family & \\
\hline & $\begin{array}{l}\text { Corrected household } \\
\text { income }\end{array}$ & \\
\hline
\end{tabular}

Table 4. Independent variables (categorical and quantitative variables) 
Second, in order to compare income for different years, we measure income via the 1st and 9 th deciles of the distribution, as well as the median and the 1st and 3rd quartile. This is a new way to measure this variable.

\section{Activity model}

We use binary logistic regression methodology because it is appropriate when the dependent variable is dichotomous (active or inactive) and because we want to obtain probabilities under certain conditions. We use a similar methodology as Sánchez-Sellero and Sánchez-Sellero (2013). They estimate a wage model in only one year, whereas we propose an activity model during three years. Thus, our model let us to know if the economic cycle plays some role in these probabilities.

\subsection{Econometric specification}

Before applying the logit model, we formulate the following hypothesis:

- H1: The model with the best results is the model in which all variables interact with gender (general model).

We estimate different versions in verify our initial idea rather than to choose the best model. Accordingly, we follow four steps.

First, we choose one of the independent variables that do not interact with gender, keeping the other variables disaggregated. Second, we estimate the model (restricted model). Third, we repeat this process as many times as the number of variables. Fourth, we compare these different models with the model in which all the variables interact with gender (general model).

We choose the most appropriate model via the contrast-likelihood ratio:

$$
-2 \ln L_{r}-\left(-2 \ln L_{g}\right) \rightarrow X_{n-m}^{2}
$$

where $L$ denotes likelihood, $r$ refers to the restricted model, $g$ refers to the general model, $n$ is the number of parameters of the general model, $m$ is the number of parameters of the restricted model and $X_{n-m}^{2}$ the chi-square distribution with $n-m$ degrees of freedom.

We estimate different versions, which constitute the general model and various restricted models. Gender interacts with all the other explanatory variables in the general model. For each restricted specification, the effect of an explanatory variable is the same for men and 
women, while we maintain the interaction with the others. We consider seven explanatory variables in addition to gender, for a total of seven restricted models. We reject the null hypothesis in all cases $(p<0.01)$, which means that the best model is the general model (see table 5). Accordingly, we consider the general model in a later logit study. This result agrees with Sánchez-Sellero and Sánchez-Sellero (2013).

\begin{tabular}{|c|c|c|c|c|c|c|c|c|c|}
\hline \multirow[b]{2}{*}{ VARIABLES } & \multicolumn{3}{|c|}{ YEAR 2003} & \multicolumn{3}{|c|}{ YEAR 2007} & \multicolumn{3}{|c|}{ YEAR 2012} \\
\hline & Dof & Chi & p-value & Dof & Chi & p-value & Dof & Chi & p-value \\
\hline Age & 8 & 12912.70 & 0.00 & 8 & 12521.65 & 0.00 & 8 & 5826.55 & 0.00 \\
\hline Marital status & 3 & 13168.33 & 0.00 & 3 & 17081.18 & 0.00 & 3 & 8819.23 & 0.00 \\
\hline $\begin{array}{c}\text { Formation } \\
\text { level }\end{array}$ & 4 & 7643.35 & 0.00 & 4 & 2533.46 & 0.00 & 4 & 1110.73 & 0.00 \\
\hline Nationality & 1 & 13.71 & 0.00 & 1 & 538.76 & 0.00 & 1 & 387.68 & 0.00 \\
\hline $\begin{array}{l}\text { Size of the } \\
\text { municipality }\end{array}$ & 1 & 44.24 & 0.00 & 1 & 4.94 & 0.03 & 1 & 857.95 & 0.00 \\
\hline $\begin{array}{c}\text { Size of the } \\
\text { family }\end{array}$ & 1 & 2907.86 & 0.00 & 1 & 4378.74 & 0.00 & 1 & 3522.50 & 0.00 \\
\hline $\begin{array}{l}\text { Corrected } \\
\text { household } \\
\text { income }\end{array}$ & 1 & 4277.81 & 0.00 & 1 & 6290.36 & 0.00 & 1 & 3737.89 & 0.00 \\
\hline
\end{tabular}

Table 5. Main results in restricted models. Contrast the validity of the restrictions that define. IGE (2003, 2007, 2012), "Family's Living Conditions Survey"

After we obtain the coefficients of the logit estimation, we calculate the probabilities of activity in men and women 20 and 64 years old. We calculate these probabilities in line with other studies that use the same methodology (with minor differences concerning, for example, the calculation of the probabilities in the case of quantitative variables).

To analyze the influence of each categorical variable on the probability of activity, we fix two variables: nationality and size of the municipality. We only consider Spanish people who live in big municipalities (with more than 20,000 people). We change the rest of the variables.

To calculate the different probabilities, we substitute the value of the coefficients from the following logit model formulation:

$$
p=\frac{1}{1+e^{-\left(\beta_{0}+\beta_{1} x_{1}+\ldots+\beta_{k} X_{k}\right)}}
$$


With the exception that for the quantitative variables, we multiply each coefficient by the corresponding average, as follows:

- Parameter corrected earnings man / woman * average income of corrected earnings man / woman

- Parameter size of the family man / woman * average size of the family man / woman

The number probabilities that we can calculate is still very large even if we fix two categorical variables, because there are many combinations of the rest of the qualitative variables. If we analyze the influence of each quantitative variable on the probability of activity, we fix all categorical variables (we assume that we start with people who live in big municipalities, are married, are between 55 and 59 years old and who formation level is the first stage of secondary). We use these categories because they encompass a large, representative population. If we analyze the influence of family size on the probability of participation in the labor market, we proceed as follows:

- Parameter corrected earnings man / woman * average income of corrected earnings man / woman

- Parameter family size man / woman * family size value (variable)

If, on the contrary, we analyze the influence of corrected earnings on the probability of participating in the labor market, we proceed as follows:

- Parameter corrected earnings man / woman * value of corrected earnings man / woman (variable)

- Parameter family size man / woman * average family size man / woman

\section{Results and discussion}

Table 6 shows the statistical results of the activity model for different years. We consider these values good for three years, the $\mathrm{R}^{2}$ is not very high but is always less than in ordinary least squares regression. 


\begin{tabular}{|l|c|c|c|}
\cline { 2 - 3 } \multicolumn{1}{c|}{} & Year 2003 & Year 2007 & Year 2012 \\
\hline $\begin{array}{l}\text { Convergence achieved in (number of } \\
\text { iterations) }\end{array}$ & 3 & 3 & 3 \\
\hline Number of no significant coefficients & 0 & 2 & 0 \\
\hline Observations with dependent variable = 0 & 3494 & 3178 & 3355 \\
\hline Observations with dependent variable = 1 & 7352 & 7209 & 10564 \\
\hline Number of observations & 10846 & 10387 & 13919 \\
\hline Corrected predictions & $73.8 \%$ & $75.7 \%$ & $79.6 \%$ \\
\hline Sensibility of the model & $87.5 \%$ & $90.2 \%$ & $93.1 \%$ \\
\hline Specificity of the model & $45.1 \%$ & $42.8 \%$ & $36.9 \%$ \\
\hline Chi squared & 378643.9 & 399055.1 & 393983.3 \\
& $\mathrm{p}=0.000$ & $\mathrm{p}=0.000$ & $\mathrm{p}=0.000$ \\
\hline $\mathbf{- 2}$ log likelihood & 1674410.6 & 1628712.9 & 1344094.1 \\
\hline McFadden's R & 0.186 & 0.199 & 0.242 \\
\hline
\end{tabular}

Table 6. Main results of logit estimations of activity model in different years. IGE (2003, 2007, 2012), "Family's Living Conditions Survey"

We present the main results of the different activity probabilities, as well as some graphical representations that support these conclusions (all representations refer to the man-woman dichotomy).

We begin by analyzing the influence of formation level on the probability of activity. In general, the higher the formation level, the higher the probability that a person is active in the labor market. In 2003 and 2007, the highest probability of labor market activity among men and women occurs when the worker has the highest level of professional training. In 2012, in which was during a crisis period, the formation level that is more probable to be active is the university studies and it is not due to a decrease in high-level professional training. For this purpose, we choose married people who are 30-34 and 55-59 years old (see Figure 1).

We find a high increase in the probability of activity in 2012, particularly in women, as a result of the crisis. The distances between the curves of both genders shrink when the formation level increases.

Next, we study the influence of age on the probability of activity. In the years of economic growth (2003 and 2007), men 30-34 years old and women 25-29 years old have the highest probability of activity. However, during the crisis period (2012), the highest probability of activity is 30-34 years regardless of gender. To determine how the probability of labor market participation varies according to age, we evaluate married people with the first period of secondary studies and with college degrees (see Figure 2). 


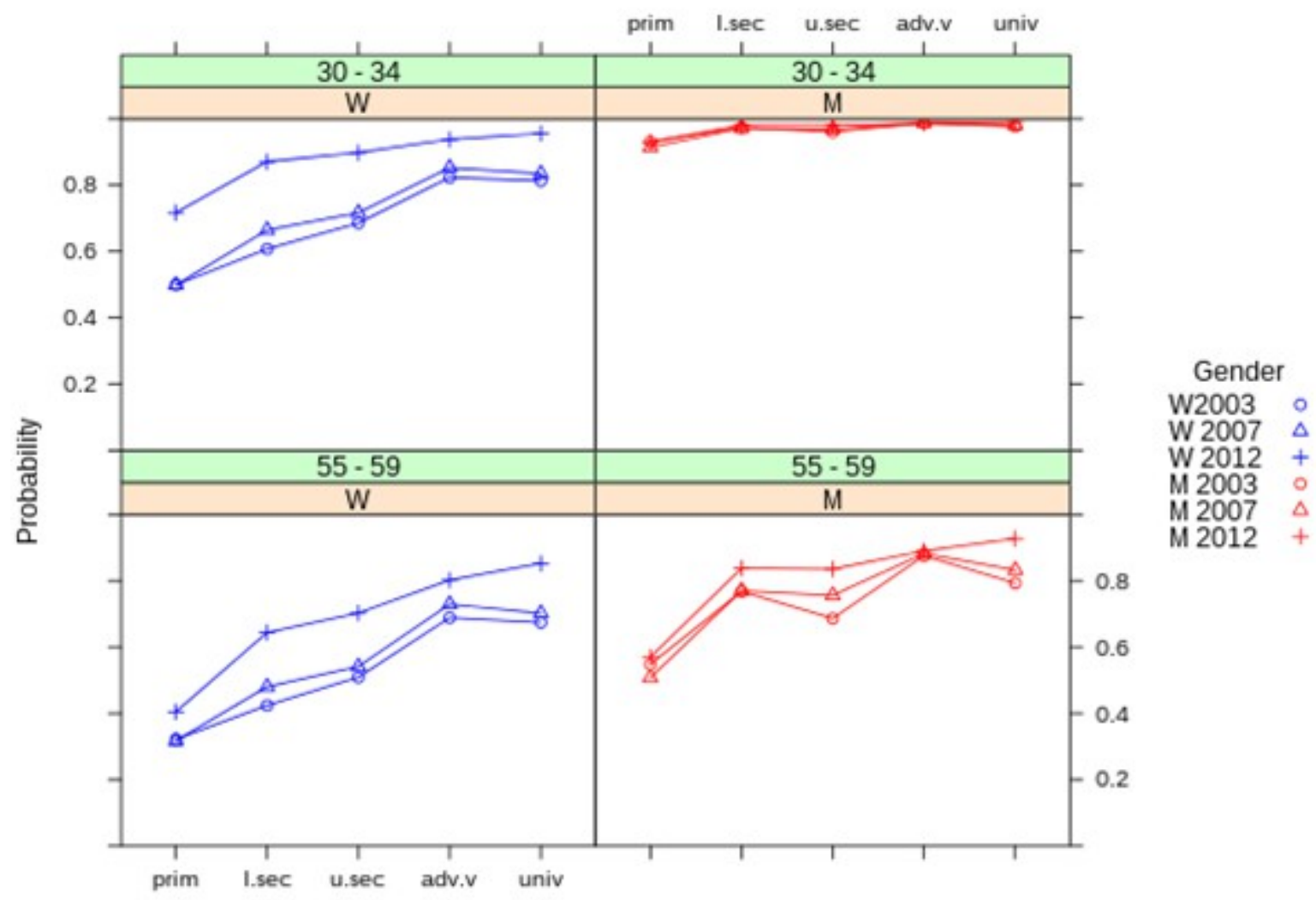

Education

Note: gender: w: women, m: men; education: prim: Illiterate and primary studies, I.sec: first period of secondary studies, u.sec: second period of secondary studies, adv.v: advanced vocational training, univ: University studies.

Figure 1. Influence of education level on the probability of being active in the labor market: Spanish, big municipalities, married. Separated by age and gender. IGE (2003, 2007, 2012), "Family's Living Conditions Survey"

We find that the probability of labor market participation significantly increases for women in 2012 over previous years. The same probability for men (Figure 2) is similar in all years (2003, 2007 and 2012) until age 40, but after 40 there is an increase in the probability of activity during a crisis period. During economic growth (2003 and 2007), men left younger the labor market, but during the economic crisis (2012) they extend their stay in the labor market.

The probability of activity in women (Figure 2) changes dramatically in 2003 and 2007, and the probability for women 30-34 years old is lower than in previous and subsequent intervals. However, this reduction disappears in 2012. Women ages 30-34 years become likely to want to work at that time, similar to men. This period coincides with the need for childcare, the cost of which could be one explanation for the change. 


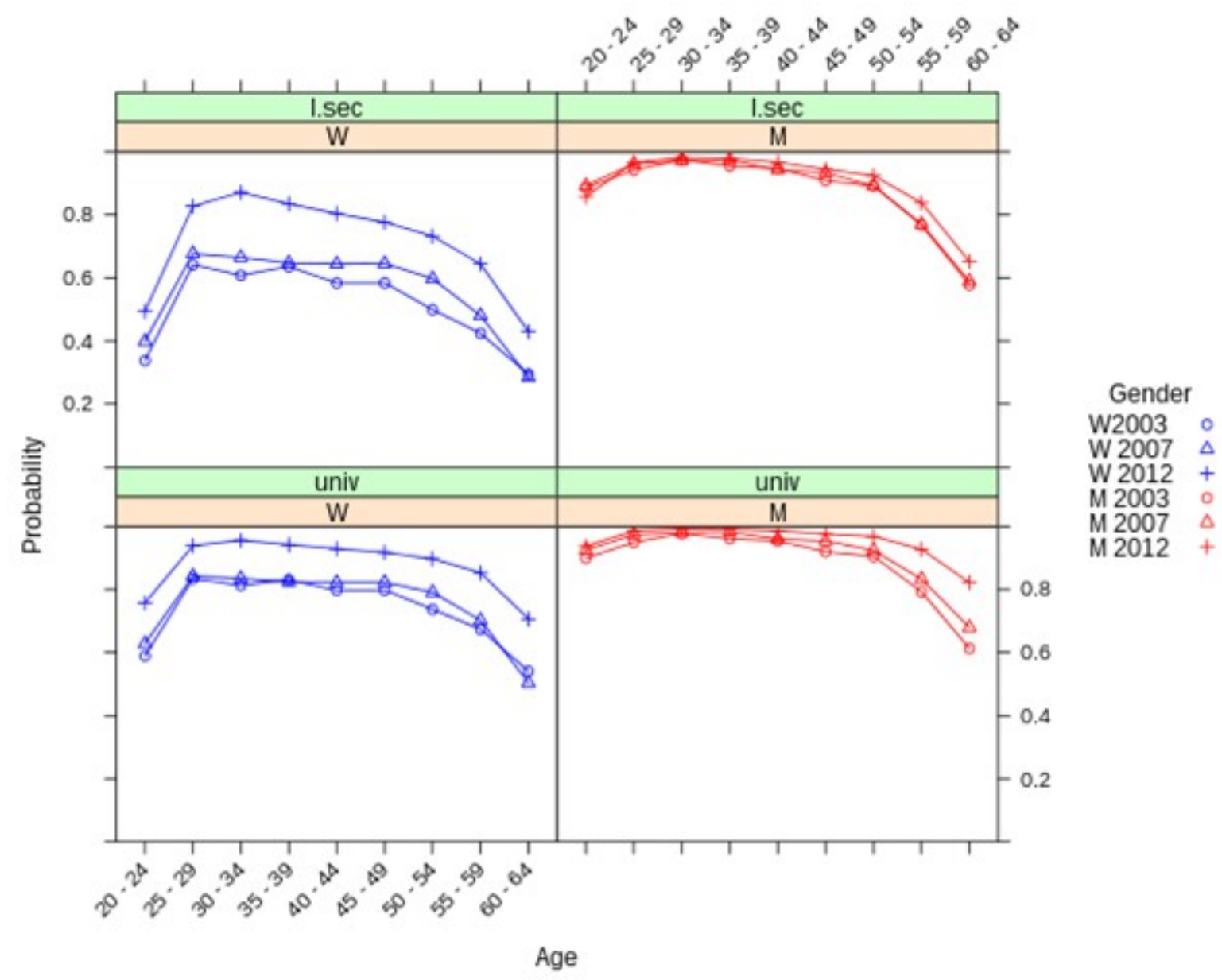

Note: gender: w: women, $\mathrm{m}$ : men.

Figure 2. Influence of age on the probability of being active in the labor market: Spanish, big municipalities, married. Separated by educational level and gender. IGE (2003, 2007, 2012), "Family's Living Conditions Survey"

Regarding the influence of marital status on the probability of activity, we start with married people because it is the largest group (Figures 1 and 2). In general, separated/divorced women are more active in the labor markets than single, married and widowed women. The probability of activity among married women increases substantially in 2012, bringing them statistically closer to the men. Similarly, married men have the highest probability of activity. This pattern does not change during the economic crisis, except for the oldest men, who increase their probability of activity. Single men and widowed women have the lowest probability of activity. 
In Figure 3, we choose people who have completed the first stage of secondary studies and are age 30-34 and 55-59 years old.

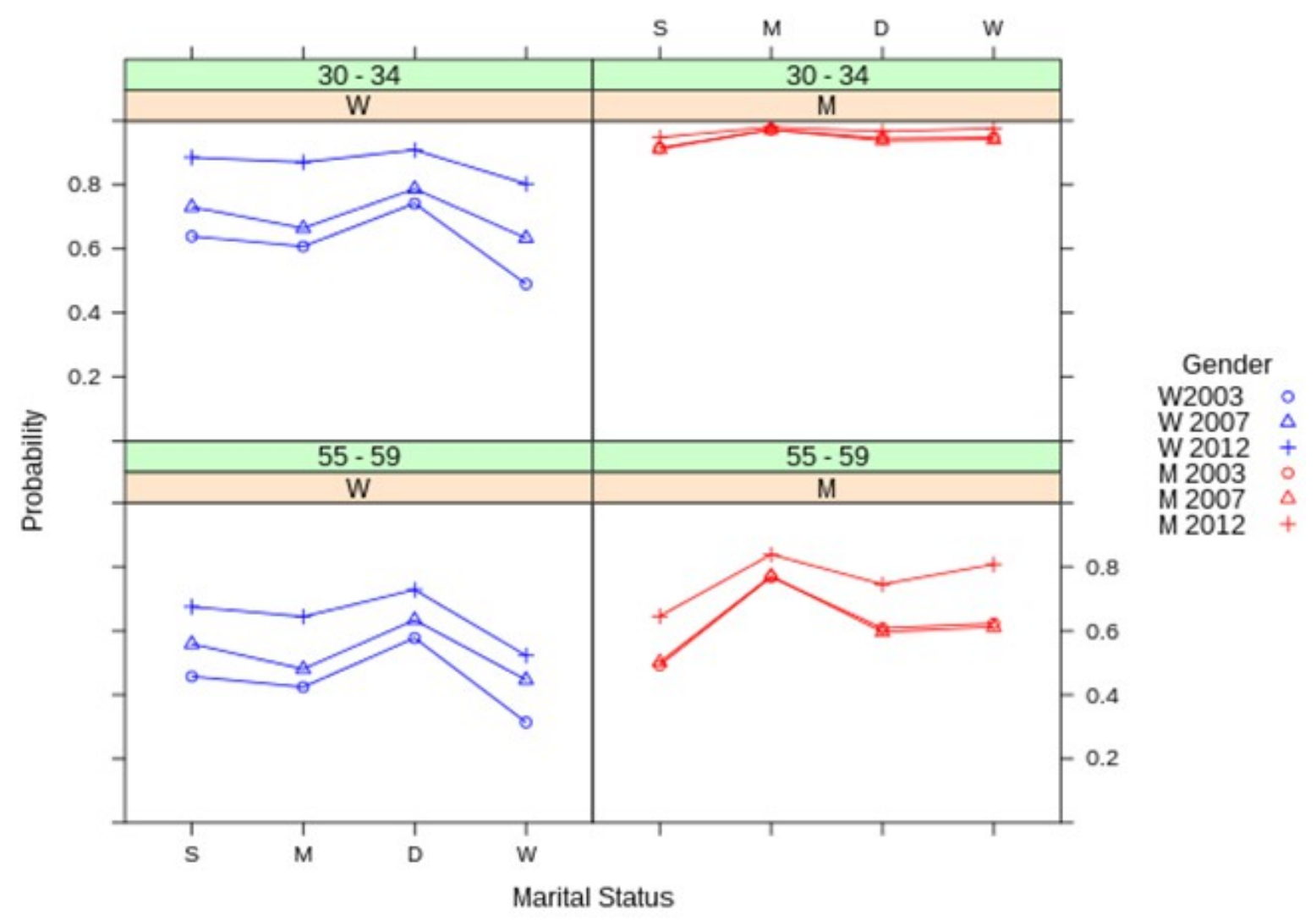

Note: gender: W: women, M: men; marital status: S: singles, M: married, D: separated / divorced, W: widowers or widows.

Figure 3. Influence of marital status on the probability of being active: Spanish, big municipalities, first period of secondary studies. Separated by age and gender. IGE (2003, 2007, 2012), "Family's Living Conditions Survey"

Figure 4 shows the influence of family size on the probability of activity. We choose married people who have completed the first stage of secondary studies and are 55-59 years old to explain probability by family size (see Figure 4).

We find that the higher the number of household members, the higher the probability of activity regardless of gender. The increase is higher for men than women. Also, we show that the curve slope is higher in 2012 than in 2003 for men and women, as is the probability of activity in the economic crisis period. Thus, if there are more people in the household, the probability of activity increases more for men than women. The probability of activity increases for both genders during the economic crisis. 


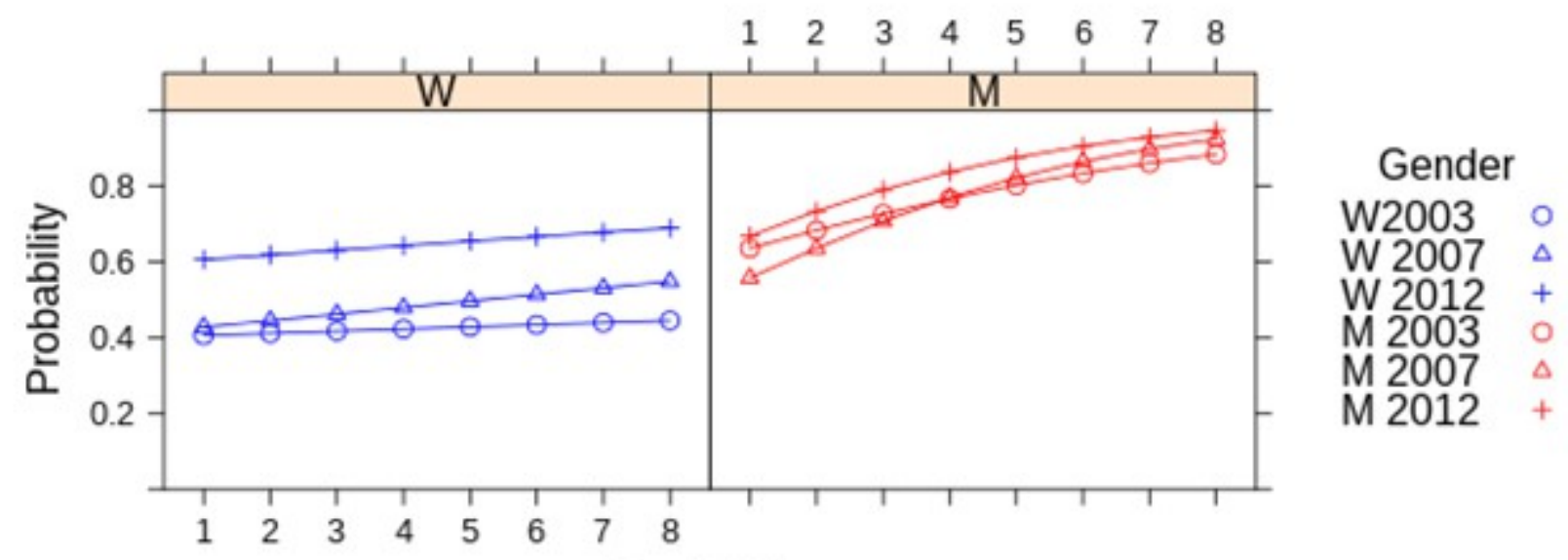

Family Size

Note: gender: W: women, M: men. Family size is the number of people who live in a household.

Figure 4. Influence of family size on the probability of being active: Spanish, big municipalities, married, first period of secondary studies and 55-59 years old. Separated by gender. IGE (2003, 2007, 2012),

"Family's Living Conditions Survey"

We show the influence of the corrected earnings on the probability of activity in figure 5 . The values of incomes correspond to 1 st and 9th deciles, median and 1st and 3rd quartiles. We choose married people who completed the first stage of secondary and who are 55-59 years old.

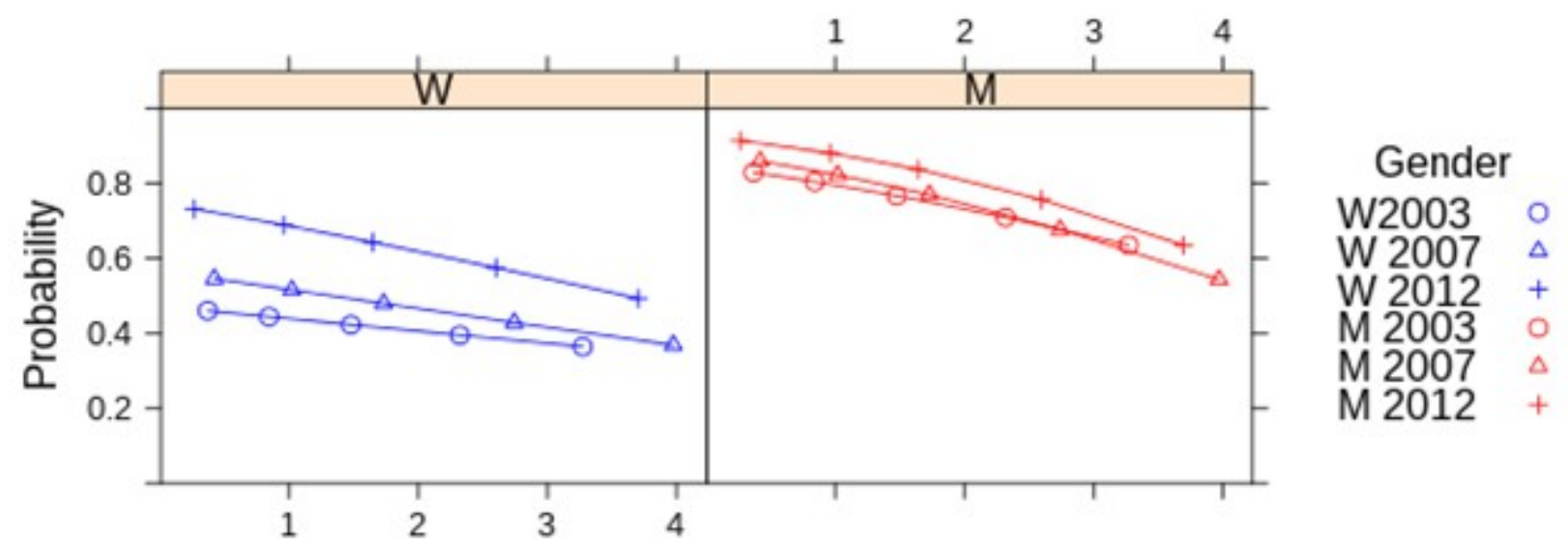

\section{Corrected Earnings}

Note: gender: W: women, M: men. Corrected Earnings is measured in thousands of Euros per month.

Figure 5. Influence of corrected earnings on the probability of being active: Spanish, big municipalities, married, first period of secondary studies and 55-59 years old. Separated by gender. IGE (2003, 2007, 2012), "Family's Living Conditions Survey" 
We find that if corrected earnings increase, the probability of activity decreases in men and women, although unevenly. The changes are always negative and they increase when incomes are bigger. The decreases in probabilities are larger for men, suggesting that men are more sensitive to decreases in the probability of activity when family income increases. Both probabilities and curve slopes are higher in 2012 than in 2003 for both genders.

\section{Conclusions}

Considering the previous literature about the labor market, gender and activity, this paper has two objectives. The first objective is to calculate the different probabilities in the man-woman duality by setting out different premises. The empirical analysis shows that our activity model is better than other hypothetical models (called restricted models) where the explanatory variables do not interact with gender. For this reason, we create recognize the importance of gender influence on the labor market. Second, we analyze the effects of the economic cycle on the probability of entering the labor markets. We repeat this study in 2003 (economic growth), 2007 (the year before the beginning of the economic crisis) and 2012 (during the economic crisis).

We find that the labor-market participation rate increases between 2007 and 2012 for the 2064 age group. In some situations, the improvement starts slightly in 2007, but the change is enormous between 2007 and 2012. This is due to general increases in situations where the participation rate was low and improvable and it is especially the case for married women.

The activity probabilities obtained through binary logistic regression show that behaviour varies by gender and that these variances remain regardless of the economic cycle. The probability of activity increases during the economic crisis, especially for women. Men retire earlier from the labor market during economic growth, whereas the probability of activity increases with age during the economic crisis (particularly for people over 55 years old). The current trend is to lengthen the years that a person is part of the labor market.

One of the highlights is that in 2012, the probability of activity in women reaches the maximum in the 30-34 age group. Before 2012, this age range suffers a decrease in relation to other age groups. In this age group, women are less likely to enter the labor markets during the economic crisis, but this probability decreases during economic growth. This suggests that women work due to the scarcity of economic resources.

We also find that if the number of family members increases, the probability of activity increases too. During the economic crisis, the slopes of the curves are higher, but if corrected 
earnings increase, the probabilities of activity decrease (in different ways for men and women). This is a new and original way to evaluate corrected earnings. The relationship between family size and corrected earnings on the probability of activity is linear.

Women almost always work outside the home: in factories, in fields, or in services. Currently, they are more educated and get better jobs, but their incorporation into the labor market under equal conditions is one of society's great challenges. Generally speaking, college graduates have more job opportunities in the labor market and we find that when education levels increase for both genders, the labor behaviour of men and women is similar.

Though this evidence suggests that gender inequalities fall over time, the economic cycle affects access to the labor market. During economic growth, middle-aged men are highly likely to enter the labor markets; hence, during the economic crisis the probability of activity hardly changes. However, women are more likely to enter the labor market than men during the economic crisis. This further reduces gender differences.

When unemployment rates are still so high (24,47\% in second quarter of 2014), many women are the primary breadwinners in many families, especially young families that rely on government support.

This paper uses data from the Galician region. We believe the findings could be extrapolated to Spain, but this assumption may not be correct without corresponding empirical analysis. The reasons for the increase in the probability of activity during the economic crisis may be obvious but need further deep analysis as well. The possibilities to expand and extend this study, as we have seen, are many and varied.

\section{Acknowledgements}

This study was supported by the Spanish Ministry of Economy and Competitiveness and FEDER (project ECO2012-36290-C03-01), the Regional Government of Aragón and FSE (project S17 and S125) and Universidade da Coruña. 


\section{References}

AGRESTI, A. (1996). An introduction to categorical data analysis. New York: Wiley. http://dx.doi.org/10.1002/(sici)1097-0258(19971030)16:20<2383::aid-sim664>3.0.co;2-0

ALBERT, C.; JUÁREZ, J.P.; SÁNCHEZ, R.; TOHARIA, L. (2003). Del sistema educativo al mercado de trabajo: Un análisis de flujos. Revista de Educación, 330: 137-155.

AMEMIYA, T. (1981). Qualitative response model: a survey. Journal of Economic Literature, 19: 481-536.

ARES, J.J.; REY, P.M. (2008). El mercado de trabajo gallego desde la entrada en Europa. Revista Galega de Economía, 17(extraordinario): 263-282.

BECKER, G. (1962). Investment in human capital: a theoretical analysis. The Journal of Political Economy, 70(5): 9-49. http://dx.doi.org/10.1086/258724

BECKER, G. (1971). The economics of discrimination. Chicago: Chicago University Press. http://dx.doi.org/10.7208/chicago/9780226041049.001.0001

BECKER, G. (1985). Human Capital, effort and the sexual division of labour. Journal of Labor Economics, 3: 33-58. http://dx.doi.org/10.1086/298075

BULOW, J.; SUMMERS, L. (1986). A theory of dual labor markets with application to industrial policy, discrimination and keynesian unemployment. Journal of Labor Economics, 4: 376-414. http://dx.doi.org/10.1086/298116

COX, D.R.; SNELL, E.J. (1989). The analysis of Binary Data. Londres: Chapman and Hall.

DEL RÍO, C. (2003). ¿Existe discriminación de xénero no mercado de traballo?. In Xosé H. Vázquez-Vicente (Ed.), Vigo, Economía e Sociedade (pp. 307-332). Vigo: Edicións Xerais de Galicia.

FRUTOS, L.; TITOS, S. (2001). Formación y trabajo autónomo desde la perspectiva de género. X Jornadas de la Asociación de Economía de la Educación, Murcia, 309-320.

GOLDIN, C. (1986). Monitoring costs and occupational segregation by sex: An historical analysis. Journal of Labor Economics, 4: 1-27. http://dx.doi.org/10.1086/298091

GRADÍN, C.; OTERO, M.; ARÉVALO, R. (2003). Elementos explicativos de la desigualdad en Galicia. Género, Mercado de Trabajo y Vivienda. Monografía 18, Instituto de Estudios Económicos de Galicia- Pedro Barrié de la Maza.

GUZMÁN, J.; RODRÍGUEZ, M.J. (2008). Comportamiento de las mujeres empresarias: una visión global. Revista de Economía Mundial, Universidad de Huelva, 18: 381-392.

HOSMER, D.W.; LEMESHOW, S. (1989). Applied Logistic Regression. New York: Wiley. 
IGE, INSTITUTO GALLEGO DE ESTADÍsTICA (2003). Encuesta de condiciones de vida de las familias, Metodología. Santiago de Compostela: Mimeo.

IGE (2007). Encuesta de condiciones de vida de las familias, Metodología. Santiago de Compostela: Mimeo.

IGE (2012). Encuesta de condiciones de vida de las familias, Metodología. Santiago de Compostela: Mimeo.

IVIE, INSTITUTO VALENCIANO DE INVESTIGACIONES ECONÓMICAS (2006). El acceso de los jóvenes al mercado laboral. Cuadernos de Capital Humano, 72(diciembre).

IVIE (2008a). Capital humano y ciclo vital en España. Cuadernos de Capital Humano, 90 (junio).

IVIE (2008b). Diferencias salariales ligadas al nivel educativo. Cuadernos de Capital Humano, 92(agosto).

LAMAS, M. (2000). El Género. La construcción cultural de la diferencia sexual. Programa Universitario de Estudios de Género, UNAM, México.

LARRAÑAGA, M. (2000). Análisis teóricos de la desigualdad, Área temática 3. Economía feminista, available online in: http://www.ucm.es/info/ec/jec7/pdf/com3-6.pdf (Last access date: March, 2012).

MÉNDEZ, J.L. (2000). Características estructurais do mercado de traballo de Galicia. Revista Galega de Emprego, 0: 53-73.

MOLTÓ, M.L.; PERAITA DE GRADO, C.; SÁNCHEZ, M.; URIEL, E. (1994). Elección de método e intensidad de búsqueda de empleo en los desempleados. Revista de Economía Aplicada, II(4): 53-74.

OGUIZA, A.; GALLASTEGUI, I.; NÚÑEZ, V. (2004). La población ocupada en la CAPV (19931999). Género y formación como características relevantes. Estadística Española, 46(156): 229-292.

R CORE TEAM (2012). R: A language and environment for statistical computing. R Foundation for Statistical Computing, Vienna, Austria, available online in: http://www.R-project.org/.

RIOBÓO, I.; MARTÍN, C. (2011). Género y mercado de trabajo en Galicia. Análisis de equidad mediante indicadores sintéticos. Revista Galega de Economía, 20(extraordinario): 1-13.

ROSENER, J. (1990). Ways women lead. Harvard Business Review, 68(6): 119-125.

SÁNCHEZ, E.; DELICADO, C. (2007). Mujeres, juventud y mercado de trabajo en España. Madrid: Consejo de la Juventud de España. 
SÁNCHEZ, S.M.; FUENTES, F.J.; ARTACHO, C. (2007). La perspectiva de género en el análisis de la satisfacción laboral: una aplicación empírica mediante modelos logit y probit. Cuadernos de Gestión, 7(2): 55-67.

SÁNCHEZ-SELLERO, M.C. (2010). Factores determinantes para la inserción y distintas formas de participación en el mercado laboral gallego. Tesis Doctoral, Universidade da Coruña.

SÁNCHEZ-SELLERO, M.C.; SÁNCHEZ-SELLERO, P. (2013). El modelo de salarización en el mercado laboral gallego: Influencia del género. Intangible Capital, 9(3): 678-707. http://dx.doi.org/10.3926/ic.422

SARKAR, D. (2008). Lattice: Multivariate Data Visualization with R. New York: Springer. http://dx.doi.org/10.1007/978-0-387-75969-2

XUNTA DE GALICIA (CONSELLERÍA DE TRABALLO). (2010). Estudio para la detección de ocupaciones laborales con posibilidad de movilidad transfronteriza entre Galicia y Norte de Portugal, available online in: http://www.ibermovilitas.org/presentacion/files/Estudio\%20Ibermovilitas \%20protegido.pdf. (Last access date: April, 2012).

XUNTA DE GALICIA, UE, MINISTERIO DE TRABAJO Y ASUNTOS SOCIALES. (2007). Programa Operativo FSE de Galicia 2007-2013.

Intangible Capital, 2015 (www.intangiblecapital.org)

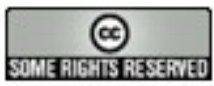

Article's contents are provided on a Attribution-Non Commercial 3.0 Creative commons license. Readers are allowed to copy, distribute and communicate article's contents, provided the author's and Intangible Capital's names are included. It must not be used for commercial purposes. To see the complete license contents, please visit http://creativecommons.org/licenses/by-nc/3.0/. 